\title{
Experiences of Learning from a Person-Centred Web-Based Support Programme for Children with Urogenital and Bowel Malformation
}

\author{
Hoa Duong1, Margaretha Jenholt Nolbris ${ }^{1,2,3}$, Agneta Simeonsdotter Svensson ${ }^{1,4}$, \\ Anna-Lena Hellström ${ }^{1,2}$ \\ ${ }^{1}$ The Center for Person-Centered Care (GPCC), University of Gothenburg, Gothenburg, Sweden \\ ${ }^{2}$ The Institute of Health and Care Sciences, Sahlgrenska Academy, University of Gothenburg, Gothenburg, Sweden \\ ${ }^{3}$ The Center for Children's Right to Health, Queen Silvia Children's Hospital, Gothenburg, Sweden \\ ${ }^{4}$ Department of Education, Communication and Learning, University of Gothenburg, Gothenburg, Sweden \\ Email: annalena.hellstrom@fhs.gu.se
}

How to cite this paper: Duong, H., Nolbris, M. J., Svensson, A. S., \& Hellström, A.-L. (2017). Experiences of Learning from a Person-Centred Web-Based Support Programme for Children with Urogenital and Bowel Malformation. Psychology, 8, 363-372.

https://doi.org/10.4236/psych.2017.83022

Received: January 9, 2017

Accepted: February 12, 2017

Published: February 16, 2017

Copyright $\odot 2017$ by authors and Scientific Research Publishing Inc. This work is licensed under the Creative Commons Attribution International License (CC BY 4.0).

http://creativecommons.org/licenses/by/4.0/

\begin{abstract}
The purpose was to illuminate preschool children's experiences of learning from a web-based intervention comprising person-centred learning support. A qualitative method was chosen based on open-ended interviews with ten children born with urogenital or bowel malformation. The data were analysed using qualitative content analysis. Two main categories and eight subcategories were identified. The findings show that the participants remembered the web preschool with pleasure and thought it had been useful. The children were able to express what they found important and in the conversations they easily associated the intervention with events in their daily life. Most of the children in this present study could manage toilet visits by themselves but worried about the standard in the school toilets. Their own integrity was important with regard to toilet matters and they wanted privacy for their visits.
\end{abstract}

\section{Keywords}

Preschool Children, Learning, Web-Based Support, Toilet Matters, Content Analysis, Urogenital and Bowel Malformation

\section{Introduction}

The current paper presents results from a person-centred web-based preschool intervention programme for children born with urogenital and bowel malformations. Children suffering from long-term illnesses, particularly of the urogenital and bowel region, are vulnerable while they are growing up (Berntsson et al., 2007; Ebert et al., 2005; Hellstrom et al., 2006; Holmdahl et al., 2007; Wilson et 
al., 2007). Before they reach school age the parents can support them, but when they start school they are alone and are not prepared for the school environment. They can feel different and find it difficult to protect their integrity and in trying to overcome this problem they might ignore their physical needs in favour of psychological wellbeing. It is important to be like other children but poor compliance with their treatment puts them at risk of ill health (Berntsson et al., 2007; Ebert et al., 2005; Hellstrom et al., 2006; Holmdahl et al., 2007; Wilson et al., 2007).

For these children prevention is to be preferred to treatment. The benefits of prevention, however, are not always easy to measure and usually large numbers of participants, control groups and a long-term perspective are required in any studies aimed at achieving this (Mantel \& Haenszel, 1959; Polit \& Beck, 2006). The incidence of the above-mentioned severe malformations is fortunately rare, which explains the low number of possible participants and the lack of prevention studies. The present study does not meet the requirements for evaluating prevention but does illuminate the learning outcomes from the intervention 1 1.5 years after its completion, from the child's point of view.

A web-based intervention comprising person-centred learning support has been developed to strengthen self-esteem and prevent ill health in pre-school children born with urogenital and bowel malformations (Hellstrom et al., 2012; Jenholt Nolbris et al., 2016; Jenholt Nolbris et al., 2016; Hellström et al., 2016). The programme was available on the web and was supported by once-a-month sessions with a "web teacher" in the form of Skype conversations. The programme was made up of sections dealing with themes about relations, their own body and emotions (http://www.webbförskolan.se). As a starting point, the children were encouraged to talk about their own experiences of different situations related to fictive stories told by Max and Sara. These stories were also available in booklet form, sent to the children by ordinary mail. During the Skype conversations the child successively developed the language skills and vocabulary suitable for telling Max and Sara's stories. The children acquired the ability to talk about past emotions; they also got the words they need to express their thoughts (Hellstrom et al., 2012; Jenholt Nolbris et al., 2016; Jenholt Nolbris et al., 2016; Hellström et al., 2016). Their self-esteem and health improved (Simeonsdotter Svensson et al., 2014). The narratives, partnership and documentation have been central to the project, in line with the concepts of person-centred care (Simeonsdotter Svensson et al., 2016).

The studies of Marton and Pramling (Marton \& Pong, 2005; Pramling Samuelsson \& Asplund Carlsson, 2008; Pramling Samuelsson et al., 2013; Pramling Samuelsson, 2009) tell us how knowledge is built in childhood and the preschool years. We learn, understand, reflect and ultimately are able to transfer what we have learned to another concept. Our own knowledge is ongoing, developed through experiences, new inputs, interests and environments (Marton \& Pong, 2005; Pramling Samuelsson \& Asplund Carlsson, 2008; Pramling Samuelsson et al., 2013; Pramling Samuelsson, 2009). 
What learning means for a child, how it is remembered and how it will be used are not sufficiently studied. Specifically, is it possible for children themselves to estimate the benefits of the attempt at person-centred learning?

In order to further develop support for children through person-centred learning we have to know more about children's experiences after an intervention of this type has been completed.

The aim of the present study is to illuminate the children's experiences of learning from a web-based intervention comprising person-centred learning support for preschool children-one to one and a half years after its completion.

Significance: To our knowledge, the study is the first with this design to investigate children's experiences of learning from a web preschool. Identifying and supporting the child's ability to understand, and their desire to maintain their integrity, may help the child living with a long-term disease sustain wellbeing and self-esteem in daily life.

\section{Method}

\subsection{Design}

A qualitative inductive design with a strategic sample was used for this study (Polit \& Beck, 2016). All the children in the study were interviewed in order to explore their experiences of learning and to discover what they actually learned from the web preschool. Qualitative interviews were conducted and participants were encouraged to talk freely so that as much valuable information as possible could be obtained (Patton, 2002). The opening question was "What did you learn from the web preschoo? How do you know you learned anything? Do you feel safe concerning toilet visits? Supporting questions were asked to gain more information: "Why is it good to learn new things? Can you tell me about a situation when you learned something? Can you give us any examples?" The interviews, both in focus groups and individually, lasted approximately $30-45 \mathrm{mi}$ nutes, they were tape-recorded, transcribed verbatim and subsequently translated into English by the authors.

\subsection{Participants}

Ten children born with urogenital or bowel malformation who had participated, twelve to eighteen months earlier, in a web-based intervention concerned with person-centred learning support aimed at supporting self-esteem and health were included in the study. Seven children aged 5 - 9 years, mean age 6.5 years participated in a focus group discussion (Morgan, 1993). Three other children, aged $6-9$, mean age 7.5 , who were unable to participate in this were interviewed individually shortly after.

\subsection{Analysis}

All the interviews were compiled into a single text, which was analysed using a manifest qualitative content analysis method supported by Krippendorff (Krippendorff, 2013). Following the prescribed steps, each author read and reread the 
text to comprehend its overall meaning. Meaning units were selected from the text and given codes that accorded with the aim of the study. Preliminary subcategories were created from the codes and later clustered into categories. Each author analysed the data independently and if agreement was not achieved in the discussion that followed further analysis was carried out until consensus was reached. Table 1 shows the categories and sub-categories. In the text in brackets, the number of the participant and age in years (y) follows the quotations. Quotations from the web teacher are marked as (WT).

\section{Findings}

\subsection{General Findings}

In the focus group discussion the children looked happy and confident, gave their name and age and narrated freely. All the children participated in the discussion by relating their experiences, and agreed or disagreed when the others spoke; some children more than others. The three children interviewed individually remembered the web preschool very well and communicated spontaneously and effortlessly with their web teacher. The findings were similar to the findings in the focus group interview.

Textual analysis revealed two categories, each comprising four subcategories (see Table 1). Key words for each subcategory are underlined in the text below.

\subsection{Category Learning}

All the participants remembered the web preschool with pleasure and thought it had been useful for them in everyday life... "you know many things". (7, 5 y). However, they had difficulties describing what they had actually learned from the different themes and did not remember from where they had learned certain skills. They were unable to describe things in general terms. The children, particularly the oldest, said that they had learned about the body and its function and found that interesting. Mostly they remembered such things as the alphabets or the names of the children in the stories. One child said: “... I can count, there was a clock on" (8, $7 \mathrm{y})$. Another child said "... the body, to learn what it looks like inside". (3, $7 \mathrm{y})$.

When discussing the content presented in the web preschool they could easily associate it with events in everyday life from their preschool and school, which for them were currently in focus.

"From the web preschool I learnt all the names" (9, 9 y). // "Tell me about a

Table 1. Categories and subcategories identified from the analysis.

\begin{tabular}{ccc}
\hline Categories & Learning & Toilet matters $\mathbf{S}$ \\
\hline & Difficulties describing & Manage by themselves \\
Subcategories & Associate with events in daily life & Support if needed \\
& Speak in terms of emotions & Dirty toilets \\
& Listen, read and practice & Go in privacy \\
\hline
\end{tabular}


situation when you learnt something" (WT)// "When I play football, I win all the time."// "What do you find most interesting to learn about?" (WT). // "Playing football, but a little about reading as well,. but I am best at football” (9, 9 y). // "When do you think you stop learning?" (WT). // "You never stop, only if you break your leg and get a plaster cast” (9, 9 y). // “... stop learning when you know everything" (2, 7 y).

Concrete events could be recalled and related to but reflections or emotions, which had figured quite largely in the web preschool discussions, were rarely mentioned. They did know about what they thought were good and bad emotions in their everyday life and how to handle them. To be happy was the best thing, whilst being angry was not good. "To be happy is better, I usually laugh, then everybody was happy too" (3, 7 y) // "Silly to fight, then I go home" (9, 9 y). "If anybody is sad, you can tell him to be happy $(5,5)$. // offer him candies" $(9,9 \mathrm{y})$.

However, they often spoke in terms of emotions such as happiness, having fun and sadness. Sometimes they were upset but mostly they said they were happy. They conveyed that learning was aimed at having fun. They expressed feeling happy about winning, but also just about learning new things. "To learn is to have fun" (1, 9 y). // "It's great learning new things" (3, 7 y). // "I just laugh when someone does something funny" (5,5 y). But they also experienced not being happy. This often happened when somebody was making a disturbance, fighting or teasing. In situations when they felt unhappy, the youngest children wanted their mother to comfort them, but they knew this was not possible in school. They had various strategies for coping, such as resting for a while or some of them talked about the benefits of being close to somebody or their cuddly toy. "P $m$ happy on my birthday" (2, 7 y). // "I almost never get angry, just sad sometimes" ( $5,5 \mathrm{y})$. // "When someone hits me then I usually cry" (5, $5 \mathrm{y})$. "What would make you happy again" (WT)? "Then mother comforts me, she just takes me in her arms" (5, 5 y). "And how does that feel" (WT)? Good! (5, 5 y). // "I usually rest until it goes away" (6, 9 y). // "I usually say brrrbrrr, you are not allowed to get angry, you' re not" (10, $7 \mathrm{y})$.

How and what to learn were discussed and reflected on. Listening, reading and practising were known tools for learning. In the focus group discussion there was consensus that learning new things is good and that what they learned at web-preschool was a good preparation for school.

"Why is it good to learn new things" (WT)? "It's great" (3, 7 y). // "To learn you have to think about it, then you remember. It's good, you will be clever as an owP' $(5,5$ y). //

"How do you learn" (WT)? "You listen" (1, 9 y). // "My grandmother reads to $m e$ " (5, 5 y). //. "You can learn to tell the time and when you start in a new class you already know" (2, 7 y). // "Yes, and then you learn it and everyone can learn things" (3, $7 \mathrm{y})$.

\subsection{Category Toilet Matters}

Going to the toilet, the right to integrity and to have your privacy protected were 
often discussed at web-preschool. Many of the children had to make extra efforts when visiting the toilet due to urine leakage, changing continence aids or emptying the urinary bladder by a catheter. Some had a locker in the school toilet where they kept their things.

The oldest could manage by themselves when going to the toilet and if there was some sort of agreement their teachers supported them if needed.

They felt confident and safe when they went to the toilet by themselves. "What about when you go to the toilet" (WT)? "Oh, yes it s good, I go to toilet by myself and I can lock the door, that protects me" (6, 9 y)?// "It's good, my teacher helps me if I need it' (2, 7 y).

However, sometimes they forgot to go to the toilet during the break and only remembered when they were in class. They knew that the teachers did not like the children to go to the toilet when they were talking, at meal times or when they had information to give to all the children. Very often these children were allowed to go whenever they needed but they seldom used this privilege. "Sometimes I forget, because the teachers do not let us go to the toilet when in class, we must do it at break or before class" $(2,7 \mathrm{y})$.

Some of the older children complained about dirty toilets. They found that the toilets were not clean, smelled badly of urine and had toilet paper everywhere, which disgusted them. This situation made the child uncomfortable about going to the toilet at school. "The toilet is not cleaned very well. It smells of urine" $(5,5$ y)// "The boys' toilets are very dirty... so I always use the girls toilets" (1, 9 y)// "My teachers suggested that we could set up a camera so that you could check who did not pee in the toilet, or that they could go with each child to check before and after (the toilet visit) whether it was clean" (2, $7 \mathrm{y})$. "That is against the law" (6, 9 y). // "I use the teacher's toilet" (3, 7 y).

At the end of the discussion in response to a request from the interviewer, one of the oldest children said that he had learned to go to the toilet without telling anyone. This is a sensitive subject particularly when you have problems and in order to avoid being teased and experiencing insulting comments you may prefer to go in privacy.

"It is better not to tell anybody you want to go, otherwise they will tease you. They tease me saying bad words." (The other children became upset and started to agree). "A toilet needs to have a door, like we have at home" (10, $7 \mathrm{y})$.

\section{Discussion}

The aim of this study was to illuminate children's experiences of learning from a web-based intervention comprising person-centred learning support for preschool children 12 to 18 months after it was completed. The goal of the intervention was to maintain and strengthen self-esteem and health in children with urogenital and bowel malformations. All the children who participated found the intervention useful for learning. They found it difficult to describe exactly what they learned, but when asked, they easily related what they had learned to events in their everyday life. They often spoke in term of emotions. Being able to 
learn, means practising and listening to others. The older children, with experiences from school, pointed to the importance of integrity when and if they needed to go to the toilet in school. They were afraid of being teased.

The focus group conversation and interviews proved to be a good choice for throwing light on the children's experiences. This study design allowed us to gain access to the children's experiences of learning. It also made it possible to discuss specific aspects of the person-centred intervention. Most of the children knew each other from various family groups arranged by the hospital. Two of the interviewers had acted as their web teachers in the intervention, which probably facilitated the conversation since misunderstandings could be avoided and each child knew one adult. The findings were consistent with differences in age, confirming validity. However, some of the participating children were too young to allow for the long-term evaluation of the effects; serious problems usually arise around the ages of $9-12$ years, according to the literature (Berntsson et al., 2007; Ebert et al., 2005; Hellstrom et al., 2006; Holmdahl et al., 2007; Wilson et al., 2007). Three children had reached the age of 9, and they showed that they could deal well with the situation at school and retain their self-esteem. A new follow-up is needed when the children are older and have moved beyond the first grades in school. The limitations of the study emphasize the difficulties of measuring prevention from a short-term perspective and in a small group of children. However, this is the situation when dealing with children with rare diagnoses and long-term illness and should be taken into consideration when reading the findings.

The child's own resources together with encouragement of partnership were used in the intervention in order to develop the learning support according to PCC (Ekman et al., 2011). However, language is important for enabling one to be a partner in one's own learning. The child's narrative was the acknowledgement that the child had learned, but also the confirmation of the feeling of being a partner. Preschool children are not always used to talking with other unknown adults and they often need time to learn to know each other, as is shown in an earlier study reported by our group (Hellstrom et al., 2012).

The language used may be infantile and certain words may not be easily understood, making access to body language necessary for communication. The child may not be used to communicating experiences in words and therefore posture, gestures and facial expressions are important for achieving a full understanding of the narrative and the person. Communicating via SKYPE allowed the use of images, facilitating understanding (Jenholt Nolbris et al., 2016; Hellstrom et al., 2012; Simeonsdotter Svensson et al., 2014).

Narrative is central to understanding another person's world, but also one's own world and narrating freely produces an evocative story (Dahlberg \& Segesten, 2010). The children in the present study often immediately associated a question with their daily life. This confirms that they felt confident, but also that they had reached the last step in the learning process, according to Marton and Pramling (Marton \& Pong, 2005; Pramling Samuelsson, \& Asplund Carlsson, 
2008; Pramling et al., 2013; Pramling Samuelsson, 2009). Knowledge is power and can be used to protect self-esteem. The children understood and showed very clearly that they were able to transfer what they had learned to another concept. According to Erikson's description of the development of the child's personality, the period between the ages of three and seven years is one of intensive learning. The child will achieve a sense of initiative if they successfully accomplish what the parents expect. If not, they will be scared and anxious (Erikson, 1982). In the present study, all the children could express their experiences of learning from web preschool and associated freely with situations they found were interesting to talk about or were proud of in their daily life.

The study shows that the oldest children felt confident and secure when they went to the toilet and that they could manage toilet matters by themselves, but some of the older children complained of dirty toilets and bad smells. Using the staff toilet could be a solution. Earlier European studies have found that school toilets are a big problem and children avoid toilet visits in school (Lundblad et al., 2007; Lundblad \& Hellstrom, 2005). In a study of healthy preschool children Nguyen shows that the reason children did not use the school toilets during the school day may be multifactorial, apart from the fact that the toilets were of a low standard, dirty and smelled unpleasant, and that their own integrity could not be protected (Nguyen et al., 2013). In the present study the children knew they had the right to go the toilet when necessary but nevertheless chose to go during the break. The children knew how the teachers felt about students going to the toilet during class and protected their integrity by not claiming their privilege.

\section{Conclusion}

This study shows that the children were able to express what they found important concerning the content in the intervention and to discuss it.

They did not reproduce the context in the stories and when narrating they associated the story content with their daily life, meaning that they both felt comfortable with and knew about the subject discussed.

Most of the children in this present study could manage toilet visits by themselves but worried about the standard of school toilets.

Their own integrity was very important with regard to toilet matters and they liked their visits to be made in privacy.

\section{References}

Berntsson, L., Brydolf, M., Berg, M., \& Hellström, A.-L. (2007). School Children and Adolescents Perception of Health, Well-Being and Participation. Scandinavian Journal of Caring Sciences, 21, 419-425.

Dahlberg, K. S., \& Segesten, K. (2010). Hälsa och vårdande i teori och praxis. Stockholm: Natur \& Kultur.

Ebert, A., Scheuering, S., Schott, G., \& Roesch, W. H. (2005). Psychosocial and Psychosexual Development in Childhood and Adolescence within the Exstrophy-Epispadias Complex. Journal of Urology, 174, 1094-1098. 
https://doi.org/10.1097/01.ju.0000169171.97538.ed

Ekman, I., Swedberg, K., Taft, C., Lindseth, A., Norberg, A., Brink, E., \& Sunnerhagen, K. S. (2011). Person-Centered Care-Ready for Prime Time. European Journal of Cardiovascular Nursing, 10, 248-251. https://doi.org/10.1016/j.ejcnurse.2011.06.008

Erikson, E. H. (1982). A Review. In E. H. Eriksson, \& J. M. Eriksson (Eds.), The Life Cycle Completed (pp. 57-72). New York: W.W. Norton.

Hellstrom, A. L., Berg, M., Solsnes, E., Holmdahl, G., \& Sillen, U. (2006). Feeling Good in Daily Life: From the Point of View of Boys with Posterior Urethral Valves. Journal of Urology, 176, 1742-1746. https://doi.org/10.1016/j.juro.2006.03.120

Hellstrom, A. L., Simeonsdotter Svensson, A., Pramling Samuelsson, I., \& Jenholt Nolbris, M. (2012). A Web-Based Programme for Person-Centred Learning and Support Designed for Preschool Children with Long-Term Illness: A Pilot Study of a New Intervention. Nursing Research and Practice, 2012, 326506. https://doi.org/10.1155/2012/326506

Holmdahl, G., Sillen, U., Abrahamsson, K., Hellstrom, A., Kruse, S., \& Solsnes, E. (2007). Self-Catheterization during Adolescence. Scandinavian Journal of Urology and Nephrology, 41, 214-217. https://doi.org/10.1080/00365590601017493

Jenholt Nolbris, M. S. S. A., \& Hellström, A.-L. (2016). Skype Support for Preschool Children with Long-Term Illness-One Year Follow-Up. Psychology Research, 6, 6978.

Jenholt Nolbris, M. S. S. A., Holmdahl, G., \& Hellström, A.-L. (2016). Development of a Programme for Web-Based Support for Children-A Participatory Design in Children and Families with Urinary Tract Disorders. JSM Health Education and Primary Health Care, 1, 1001.

Krippendorff, K. (2013) Content Analysis. An Introduction to Its Methodology (3rd ed). California, CA: Sage Publications.

Lundblad, B., Berg, M., \& Hellstrom, A. L. (2007). Experiences of Children Treating Functional Bladder Disturbances on Schooldays. Journal of Pediatric Urology, 3, 189193. https://doi.org/10.1016/j.jpurol.2006.08.004

Lundblad, B., \& Hellstrom, A. L. (2005). Perceptions of School Toilets as a Cause for Irregular Toilet Habits among Schoolchildren Aged 6 to 16 Years. Journal of School Health, 75, 125-128. https://doi.org/10.1111/j.1746-1561.2005.tb06656.x

Mantel, N., \& Haenszel, W. (1959). Statistical Aspects of the Analysis of Data from Retrospective Studies of Disease. Journal of the National Cancer Institute, 22, 719-748.

Morgan, D. (1993). Successful Focus Groups: Advancing the State of Art. Newbury Park, CA: Sage. https://doi.org/10.4135/9781483349008

Patton, Q. M. (2002). Qualitative Research \& Evaluations Methods (3rd ed.). Thousand Oaks, CA: Sage Publications.

Polit, D. F., \& Beck, C. T. (2006). The Content Validity Index: Are You Sure You Know What's Being Reported? Critique and Recommendations. Research in Nursing \& Health, 29, 489-497. https://doi.org/10.1002/nur.20147

Polit, D. F., \& Beck, C. T. (2016). Nursing Research: Generating and Assessing Evidence for Nursing Practice. Philadelphia: Wolters Kluwer.

Marton, W. Y., \& Pong, F. M. (2005). On the Unit of Description in Phenomenography. Higher Education Research \& Development, 24, 335-348. https://doi.org/10.1080/07294360500284706

Pramling Samuelsson, I., \& Asplund Carlsson, M. (2008). The Playing Learning Child: Towards a Pedagogy of Early Childhood. Scandinavian Journal of Educational Re- 
search, 52, 623-641. https://doi.org/10.1080/00313830802497265

Pramling Samuelsson, I., Sommer, D., \& Hundeide, K. (2013). Early Childhood Care and Education-A Child Perspective Paradigm. European Early Child Education Research Journal, 21, 459-475.

Pramling Samuelsson, I. S. (2009). Preschool Quality and Young Children's Learning in Swede. International Journal of Child Care and Education Policy, 1, 1-12. https://doi.org/10.1007/2288-6729-3-1-1

Simeonsdotter Svensson, A. J. N. M., Holmdahl, G., \& Hellström, A.-L. (2016). Health, Wellbeing and Self-Esteem: Web-Based Support in Children with Urogenital or Bowel Malformation. Open Journal of Pediatrics, 6, 82-90.

https://doi.org/10.4236/ojped.2016.61014

Simeonsdotter Svensson, A. P. S. I., Hellström, A.-L., \& Jenholt Nolbris, M. (2014). Experiences of SKYPE Communication in Education and Research-Data Collection Concerning Young Children with Long-Term Illness. Early Child Development and Care, 184, 1017-1030. https://doi.org/10.1080/03004430.2013.841154

Nguyen, T. K. A., Vernon, S. J., Bengtson, A., \& Hellström, A.-L. (2013). Toilet Habits in Kindergarten Children in a Kindergarten in Hanoi. Open Journal of Pediatrics, 5, 1760-1767.

Wilson, C. J., Pistrang, N., Woodhouse, C. R., \& Christie, D. (2007). The Psychosocial Impact of Bladder Exstrophy in Adolescence. Journal of Adolescent Health, 41, 504508. https://doi.org/10.1016/j.jadohealth.2007.05.021

\section{Submit or recommend next manuscript to SCIRP and we will provide best} service for you:

Accepting pre-submission inquiries through Email, Facebook, LinkedIn, Twitter, etc. A wide selection of journals (inclusive of 9 subjects, more than 200 journals)

Providing 24-hour high-quality service

User-friendly online submission system

Fair and swift peer-review system

Efficient typesetting and proofreading procedure

Display of the result of downloads and visits, as well as the number of cited articles

Maximum dissemination of your research work

Submit your manuscript at: http://papersubmission.scirp.org/

Or contact psych@scirp.org 